When Do State-Owned Firms Crowd Out Private Investment?

Stefan Buehler and Simon Wey

March 2012 Discussion Paper no. 2012-9 


$\begin{array}{ll}\text { Editor: } & \text { Martina Flockerzi } \\ & \text { University of St. Gallen } \\ & \text { School of Economics and Political Science } \\ & \text { Department of Economics } \\ & \text { Varnbüelstrasse 19 } \\ & \text { CH-9000 St. Gallen } \\ & \text { Phone +41 71 224 23 25 } \\ & \text { Fax } \quad+41712243135 \\ & \text { Email seps@unisg.ch } \\ & \text { School of Economics and Political Science } \\ & \text { Department of Economics } \\ & \text { University of St. Gallen } \\ & \text { Varnbüelstrasse 19 } \\ \text { Publisher: } & \text { CH-9000 St. Gallen } \\ & \text { Phone +41 71 224 23 25 } \\ & \text { Fax +41 71 224 31 35 } \\ & \text { http://www.seps.unisg.ch }\end{array}$




\title{
When Do State-Owned Firms Crowd Out Private Investment? ${ }^{1}$
}

\author{
Stefan Buehler and Simon Wey
}

Author's address:

Prof. Dr. Stefan Buehler

Department of Economics

FGN-HSG

Varnbüelstr. 19

$\mathrm{CH}-9000$ St. Gallen

Phone +41712242303

Fax $\quad+41712242670$

Email stefan.buehler@unisg.ch

Website www.stefan-buehler.net

Simon Wey

University of Zurich

Department of Business

ISU-UZH

Plattenstr. 14

$\mathrm{CH}-8032$ Zurich

Email simon.wey@business.uzh.ch

\footnotetext{
${ }^{1}$ We thank Christian Ewerhart, Daniel Halbheer, Martin Kolmar, Markus Lang, Jochen Mankart and Mark Schelker for helpful discussions and suggestions. Financial support from the Swiss National Science Foundation through grants PP0011-114754 and PP0OP1-135143 is gratefully acknowledged.
} 


\section{Abstract}

This note examines the conditions under which a state-owned firm with a political agenda crowds out investment by a private firm. We show that crowding out occurs if the private firm regards investments as strategic substitutes and private investment is undesirable from the state-owned firm's perspective.

\section{Keywords}

Public investment, crowding out, political agenda.

\section{JEL Classification}

D43, H42, L13. 


\section{Introduction}

In many countries, state-owned firms play an important role in providing infrastructure (telecommunications, energy, railroads, etc.). Yet, state ownership is not limited to infrastructure, and rivalry between state-owned and private firms is a common phenomenon. ${ }^{1}$ While there has been considerable debate regarding the pros and cons of state-owned firms (see, e.g., Boardman and Vining, 1989; Dewenter and Malatesta, 2001; Megginson and Netter, 2001; Bogart and Chaudhary, 2012), the literature has largely ignored the important concern that state-owned firms might crowd out private investment. ${ }^{2}$ We fill part of this gap by working out the conditions under which a state-owned firm will crowd out private investment.

Specifically, we consider a duopoly setting where firms choose prices and demand-enhancing investments in line with their political agendas. Related earlier contributions include De Fraja and Delbono (1989), Cremer et al. (1991), Matsumura (1998), Matsumura and Matsushima (2004), and Ishibashi and Matsumura (2006). Yet, these papers make the peculiar assumption that stateowned firms maximize social welfare, and they typically abstract from demandenhancing investments.

Employing reduced-form functions for demands and political agendas, we characterize equilibrium prices and investments. We find that investment by the state-owned firm crowds out private investment if the private firm regards investments as strategic substitutes and private investment is undesirable from the state-owned firm's perspective. The extent to which these conditions are satisfied is likely to vary across industries, which is consistent with the mixed empirical evidence on the impact of public investment on private investment (see, e.g., David et al., 2000; González and Pazó, 2008). We illustrate our analysis with a linear demand example where the state-owned firm's political agenda is to maximize total investment.

\footnotetext{
${ }^{1}$ In the U.S., for instance, state-owned firms compete with private firms in banking, health care, education, broadcasting, and alcoholic beverages.

${ }^{2}$ A recent special report by The Economist (January 21, 2012) on "State Capitalism" provides a useful survey of the debate.
} 


\section{Analytical Framework}

Consider a duopoly model with differentiated products indexed by $i, j=1,2$. Product demand is given by $D_{i}(\mathbf{p}, \boldsymbol{\theta})$, where $\mathbf{p}=\left(p_{i}, p_{j}\right)$ and $\boldsymbol{\theta}=\left(\theta_{i}, \theta_{j}\right), i \neq j$, denote prices and investments, respectively. We assume that demand satisfies $\partial D_{i} / \partial p_{i}<0, \partial^{2} D_{i} / \partial p_{i}^{2}<0, \partial D_{i} / \partial p_{j} \geq 0, \partial D_{i} / \partial \theta_{i}>0$, and $\partial D_{i} / \partial \theta_{j} \leq 0$. Firms face constant marginal costs $c_{i} \geq 0$ and make investments at convex cost $F_{i}\left(\theta_{i}\right)$ before price competition takes place. Firm $i$ 's profits are thus given by $\pi_{i}(\mathbf{p}, \boldsymbol{\theta})=\left(p_{i}-c_{i}\right) D_{i}(\mathbf{p}, \boldsymbol{\theta})-F_{i}\left(\theta_{i}\right)$. Following Vickers and Yarrow (1991), we allow for the possibility that firm $i$ adheres to a political agenda $A_{i}(\mathbf{p}, \boldsymbol{\theta})$, such that it effectively maximizes

$$
\Pi_{i}(\mathbf{p}, \boldsymbol{\theta})=\pi_{i}(\mathbf{p}, \boldsymbol{\theta})+\lambda_{i} A_{i}(\mathbf{p}, \boldsymbol{\theta})
$$

where $\lambda_{i} \in\{0,1\}$ indicates whether firm $i$ 's behavior is affected by a political agenda.

To ensure existence and uniqueness of a price equilibrium, we assume that prices are strategic complements $\left(\partial^{2} \Pi_{i} /\left(\partial p_{i} \partial p_{j}\right) \geq 0\right)$ and that the contraction condition $\partial^{2} \Pi_{i} /\left(\partial p_{i}\right)^{2}+\left|\partial^{2} \Pi_{i} /\left(\partial p_{i} \partial p_{j}\right)\right|<0$ holds (Gallego et al., 2006; Vives, 2001). To simplify exposition, we let $\varepsilon_{i j} \equiv-\left(\partial D_{j} / \partial p_{i}\right) /\left(D_{j} / p_{i}\right)$ denote the price elasticity of demand and define the generic variables $\hat{X}_{i i} \equiv\left(\partial X_{i} / \partial p_{j}\right)\left(\partial p_{j} / \partial \theta_{i}\right)+$ $\partial X_{i} / \partial \theta_{i}$ and $\hat{X}_{i j} \equiv\left(\partial X_{i} / \partial p_{j}\right)\left(\partial p_{j} / \partial \theta_{j}\right)+\partial X_{i} / \partial \theta_{j}$.

Applying the envelope theorem, prices and investments in the interior subgame-perfect Nash equilibrium satisfy the first-order conditions

$$
\begin{gathered}
\frac{p_{i}-c_{i}}{p_{i}}=\frac{1}{\varepsilon_{i i}}\left(1+\lambda_{i} \frac{1}{D_{i}} \frac{\partial A_{i}}{\partial p_{i}}\right), \\
\left(p_{i}-c_{i}\right) \hat{D}_{i i}+\lambda_{i} \hat{A}_{i i}=\frac{\partial F_{i}}{\partial \theta_{i}} .
\end{gathered}
$$

Equations (1) and (2) nest the standard duopoly $\left(\lambda_{1}=\lambda_{2}=0\right)$, the mixed duopoly $\left(\lambda_{1} \neq \lambda_{2}\right)$, and the welfare benchmark $\left(\lambda_{1}=\lambda_{2}=1\right)$ as special cases. ${ }^{3}$ They indicate that the political agenda $A_{i}$ plays an intuitive role for equilibrium pricing and investment: The derivatives of $A_{i}$ with respect to $p_{i}$ and $\theta_{i}$, respectively, determine the extent to which equilibrium choices are distorted away from standard profit-maximizing choices.

\footnotetext{
${ }^{3}$ In the latter cases, a state-owned firm maximizes social welfare by assumption, such that $A_{i}=\pi_{j}+\int D_{i} d p_{i}+\int D_{j} d p_{j}, i \neq j$.
} 


\section{Political Agenda and Crowding Out}

We now study the conditions under which the public firm's investment crowds out private investment, using the taxonomy of business strategies introduced by Fudenberg and Tirole (1984). ${ }^{4}$

From firm $i$ 's point of view, investment makes firm $j$ soft if

$$
\frac{d \Pi_{i}}{d \theta_{j}}=\left(p_{i}-c_{i}\right) \hat{D}_{i j}+\lambda_{i} \hat{A}_{i j}>0
$$

whereas investment makes firm $j$ tough if $d \Pi_{i} / d \theta_{j}<0$. Notice that firm $i^{\prime}$ s political agenda may affect its assessment of firm $j$ 's investment. For instance, a positive effect of firm $j^{\prime}$ s investment on firm $i$ 's political agenda (i.e., $\hat{A}_{i j}>0$ ) may dominate a negative effect on profits $\left(d \pi_{i} / d \theta_{j}<0\right)$, leading to a positive overall assessment of firm $j$ 's investment $\left(d \Pi_{i} / d \theta_{j}>0\right)$.

Moreover, from firm $i$ 's point of view, investments are strategic complements if

$$
\frac{\partial^{2} \Pi_{i}}{\partial \theta_{i} \partial \theta_{j}}=\frac{\partial \hat{D}_{i i}}{\partial \theta_{j}}\left(p_{i}-c_{i}\right)+\hat{D}_{i i} \frac{\partial p_{i}}{\partial \theta_{j}}+\lambda_{i} \frac{\partial \hat{A}_{i i}}{\partial \theta_{j}}>0
$$

and strategic substitutes if $\partial^{2} \Pi_{i} /\left(\partial \theta_{i} \partial \theta_{j}\right)<0$. That is, the political agenda may also affect firm $i$ 's view of the strategic interaction in investments. In particular, a negative impact of firm $j^{\prime}$ s investment on the agenda-enhancing effect of own investment (i.e., $\left.\partial \hat{A}_{i i} / \partial \theta_{j}<0\right)$ may change the sign of $\partial^{2} \Pi_{i} /\left(\partial \theta_{i} \partial \theta_{j}\right)$ from positive to negative.

Using equations (3) and (4), Table 1 characterizes the strategic interaction in investments by a state-owned firm and a private firm. We assume that the row player is the state-owned firm $i$ with a political agenda $\left(\lambda_{i}=1\right)$ maximizing $\Pi_{i}$, whereas the column player is the private firm $j$ which maximizes profits $\pi_{j}$ (i.e., $\left.\lambda_{j}=0\right){ }^{5}$

We first consider the case where investment makes firm $j$ soft $\left(d \Pi_{i} / d \theta_{j}>0\right)$, such that private investment is desirable from the state-owned firm's point of view. In this case, the state-owned firm will want to promote (rather than crowd out) private investment. To do so, the state-owned firm will adopt a "puppy dog" strategy if investments are strategic substitutes and a "fat cat" strategy if investments are strategic complements from the private firm's point of view. It is worth emphasizing that, if the state-owned firm strategically overinvests, it does so to promote private investment.

\footnotetext{
${ }^{4}$ Functions are evaluated at equilibrium quantities throughout this section.

${ }^{5}$ The extension to the case where firm $j$ also adheres to a political agenda is straightforward.
} 
Table 1: Investment by a State-Owned Firm with a Political Agenda

\begin{tabular}{cccc}
\hline \hline & & \multicolumn{2}{c}{ Private Firm $\left(\lambda_{j}=0\right)$} \\
& & strat. substitutes & strat. complements \\
\cline { 3 - 4 } & soft & $\frac{\partial^{2} \pi_{j}}{\partial \theta_{j} \partial \theta_{i}}<0$ & $\frac{\partial^{2} \pi_{j}}{\partial \theta_{j} \partial \theta_{i}}>0$ \\
\cline { 3 - 4 } & $\frac{d \Pi_{i}}{d \theta_{j}}>0$ & "puppy dog" & $\begin{array}{c}\text { underinvestment } \\
\text { "fat cat" }\end{array}$ \\
$\left(\lambda_{i}=1\right)$ & tough & overinvestment & underinvestment \\
& $\frac{d \Pi_{i}}{d \theta_{j}}<0$ & "top dog" & "lean \& hungry look" \\
& & crowding out & \\
\hline
\end{tabular}

Next, we consider the case where private investment makes firm $j$ tough $\left(d \Pi_{i} / d \theta_{j}<0\right)$, such that private investment is undesirable from the state-owned firm's point of view. In this setting, the state-owned firm will indeed want to reduce private investment. To do so, it will adopt a "top dog" strategy if investments are strategic substitutes and a "lean \& hungry look" strategy if investments are strategic complements from the private firm's point of view. That is, the only setting in which the state-owned firm strategically overinvests to crowd out private investments is the top dog setting.

Summing up, Table 1 highlights that crowding out will occur only if the private firm regards investments as strategic substitutes and private investment is undesirable from the state-owned firm's perspective. It is worth noting that, if the political agenda does not change the sign of $d \Pi_{i} / d \theta_{j}$ from positive to negative, there is either no crowding out, or crowding out would also be practiced by a private firm without a political agenda.

\section{Linear Demand Model}

We illustrate our analysis with a linear demand example for which we can derive closed-form solutions. Specifically, assume that demand is given by

$$
D_{i}(\mathbf{p}, \boldsymbol{\theta})=\alpha-\beta p_{i}+\gamma p_{j}+\theta_{i}-\tau \theta_{j},
$$

where $\alpha>0$ and $\beta>\gamma>0$ are parameters and $\tau \in\{0,1\}$ indicates whether investment has a direct business stealing effect. Let firm 1 be the state-owned firm $\left(\lambda_{1}=1\right)$ and assume, for simplicity, that its political agenda is to maximize total investment, i.e.,

$$
A_{1}(\mathbf{p}, \boldsymbol{\theta})=\omega\left(\theta_{1}+\theta_{2}\right),
$$


where $\omega \geq 0$ measures the weight of the political agenda. ${ }^{6}$ Suppose that firm 2 is privately owned and maximizes profits $\left(\lambda_{2}=0\right)$.

Let us now employ Table 1 to characterize equilibrium behavior. Tedious but straightforward calculations show that, from firm 2's perspective,

$$
\frac{\partial^{2} \pi_{2}}{\partial \theta_{2} \partial \theta_{1}}=\frac{2 \beta(2 \beta-\gamma \tau)(\gamma-2 \beta \tau)}{\left(4 \beta^{2}-\gamma^{2}\right)^{2}}
$$

such that investments are strategic substitutes if they give rise to business stealing (i.e., $\left.\partial^{2} \pi_{2} /\left.\left(\partial \theta_{2} \partial \theta_{1}\right)\right|_{\tau=1}<0\right)$ and strategic complements in the absence of business stealing $\left(\partial^{2} \pi_{2} /\left.\left(\partial \theta_{2} \partial \theta_{1}\right)\right|_{\tau=0}>0\right)$. Firm 1's optimal behavior further depends on the weight of its political agenda. To see this, notice that $d \Pi_{1} / d \theta_{2}$ is negative at $\omega=0$ and monotone increasing in $\omega$. There is thus a critical weight $\omega^{*}(\tau)$ below (above) which investment makes firm 2 tough (soft, respectively). As a result, depending on parameter values, one of the strategies listed in Table 1 will be adopted in equilibrium.

Figure 1 illustrates the different scenarios for the parameter values $\alpha=0.5$, $\beta=1, \gamma=0.7$, and marginal costs $c_{1}=c_{2}=0$. First, consider the case of strategic substitutes $(\tau=1)$. Panel A shows that the reaction functions $R_{1}$ and $R_{2}$ are downward-sloping, and that an increase in the weight of the political agenda $\omega$ shifts out the state-owned firm's reaction function $R_{1}$. Panel B highlights that firm 1 adopts a top dog (puppy dog) strategy for $\omega$ below (above, respectively) the critical weight $\omega^{*}(1)$. That is, the state-owned firm 1 practices crowding out if investments are strategic substitutes and the weight of the political agenda $\omega$ is sufficiently small. ${ }^{7}$ Panel B also shows that investments are symmetric and do not vary in $\omega$ if both firms solely maximize profits $\left(\lambda_{i}=0, i=1,2\right)$. Next, consider the case of strategic complements $(\tau=0)$. Panel $C$ shows that the reaction functions $R_{1}$ and $R_{2}$ are now upward-sloping, and that an increase in $\omega$ shifts out $R_{1}$. Panel $\mathrm{D}$ highlights that, for the given parameter values, firm 1 adopts a fat cat strategy for any admissible $\omega \geq 0 .{ }^{8}$ The state-owned firm 1 will thus never adopt a lean \& hungry look strategy. Again, investments do not vary in $\omega$ if both firms solely maximize profits.

\footnotetext{
${ }^{6}$ Such a political agenda may be induced, for instance, by a public concern for sufficient infrastructure investments.

${ }^{7}$ Notice that crowding out would also be practiced by a privately owned firm 1 .

${ }^{8}$ The critical weight $\omega^{*}(0)$ below which firm 1 would adopt a lean \& hungry look strategy is negative.
} 


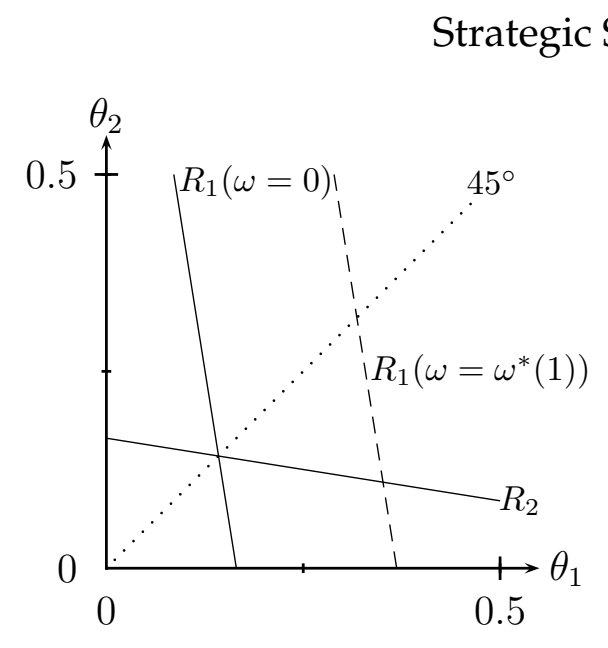

(A)

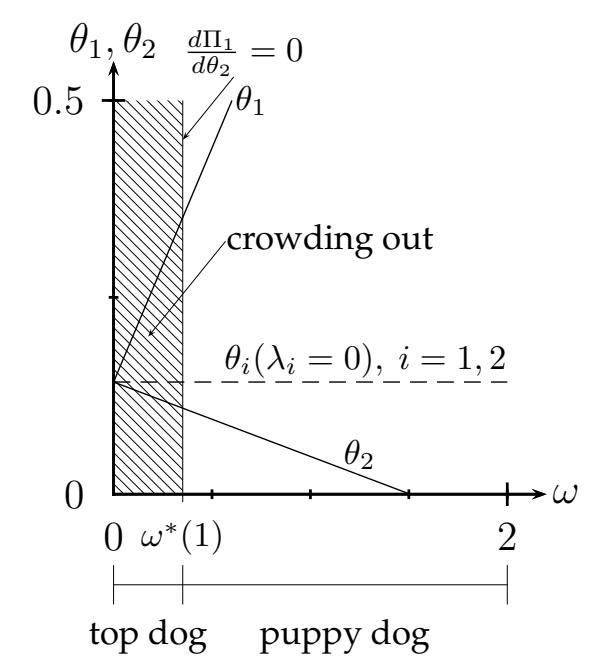

(B)

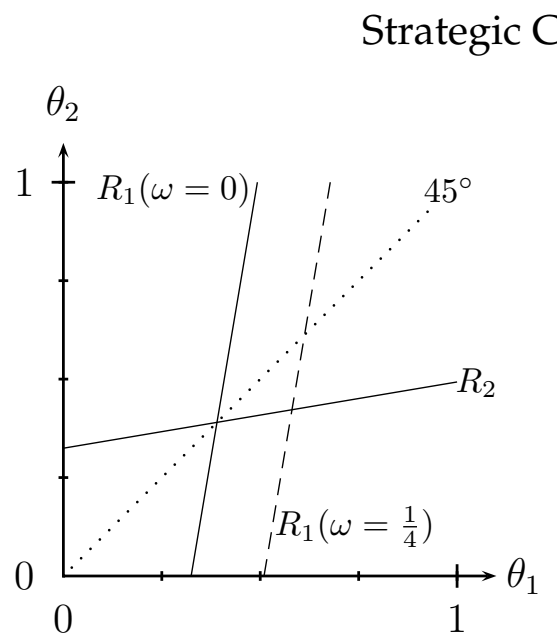

(C)

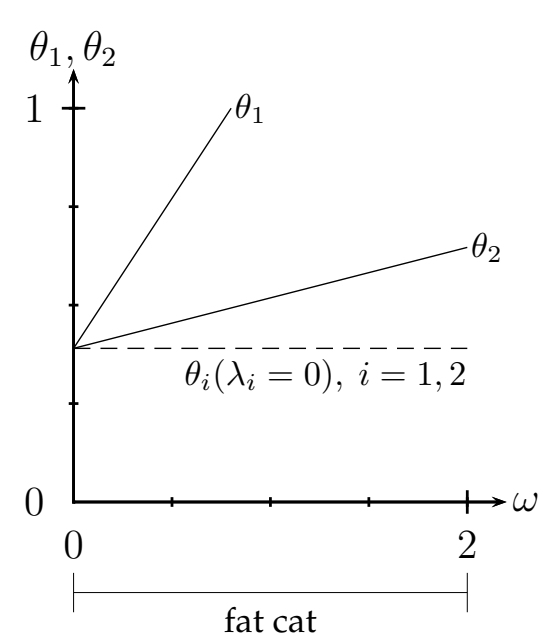

(D)

Figure 1: Reaction functions and equilibrium investments with linear demand and political agenda $A_{1}=\omega\left(\theta_{1}+\theta_{2}\right)$ 


\section{Conclusion}

We have analyzed the conditions under which a state-owned firm with a political agenda crowds out investment by a private firm. Our analysis shows that the state-owned firm crowds out private investment in markets where the private firm regards investments as strategic substitutes and private investment is undesirable from the state-owned firm's perspective.

The extent to which these conditions are satisfied is likely to vary across industries. The linear demand example highlights that investments tend to be strategic substitutes if they give rise to business stealing. Moreover, it seems plausible that state-owned firms will dislike private investment in industries where their political agenda reflects concerns with respect to public health (e.g., alcoholic beverages, pharmacy), public security (e.g., fire service, air traffic control), or environmental protection (e.g., nuclear power generation, waste disposal). In the absence of such concerns, it is not obvious why a state-owned firm should have a stronger distaste for competitor investment than a private firm. 


\section{References}

BoArdman, A. E. AND A. R. Vining (1989): "Ownership and Performance in Competitive Environments: A Comparison of the Performance of Private, Mixed, and State-Owned Enterprises," Journal of Law \& Economics, 32, 1-389.

BOGART, D. AND L. ChAudhary (2012): "Regulation, Ownership, and Costs: A Historical Perspective from Indian Railways," American Economic Journal: Economic Policy, 4, 28-57.

Cremer, H., M. Merchand, AND J.-F. Thisse (1991): “Mixed Oligopoly with Differentiated Products," International Journal of Industrial Organization, 9, 4353.

DAVID, P. A., B. H. HAll, AND A. A. ToOle (2000): “Is Public R\&D a Complement or Substitute for Private R\&D? A Review of the Econometric Evidence," Research Policy, 29, 497-529.

De Fraja, G. And F. Delbono (1989): “Alternative Strategies of a Public Enterprise in Oligopoly," Oxford Economic Papers, 41, 302-311.

Dewenter, K. L. And P. H. Malatesta (2001): "State-Owned and Privately Owned Firms: An Empirical Analysis of Profitability, Leverage, and Labor Intensity," American Economic Review, 91, 320-334.

FudenberG, D. And J. Tirole (1984): “The Fat-Cat Effect, the Puppy-Dog Ploy, and the Lean and Hungry Look," American Economic Review, 74, 361366.

Gallego, G., H. Woonghee Tim, K. Wanmo, and R. Phillips (2006): "Price Competition with the Attraction Demand Model: Existence of Unique Equilibrium and Its Stability." Manufacturing \& Service Operations Management, 8, 359-375.

GonzÁlez, X. And C. Pazó (2008): “Do Public Subsidies Stimulate Private R\&D Spending?" Research Policy, 37, 371-389.

Ishibashi, I. AND T. MATSUmuRA (2006): “R\&D Competition Between Public and Private Sector," European Economic Review, 50, 1347-1366.

Matsumura, T. (1998): "Partial Privatization in Mixed Duopoly," Journal of Public Economics, 70, 473-483. 
Matsumura, T. and N. Matsushima (2004): "Endogenous Cost Differentials between Public and Private Enterprises: A Mixed Duopoly Approach," Economica, 71, 671-688.

Megginson, W. L. AND J. M. NetTer (2001): “From State to Market: A Survey of Empirical Studies on Privatization," Journal of Economic Literature, 39, 321-389.

VicKers, J. AND G. YARROW (1991): “Economic Perspectives on Privatization," Journal of Economic Perspectives, 5, 111-132.

VIVES, X. (2001): Oligopoly Pricing: Old Ideas and New Tools, MIT Press. 